\title{
Implementasi GCG Terhadap Kinerja Sosial Perusahaan Tambang Batu Bara pada Masyarakat Lokal
}

\author{
Muhammad Subhan ${ }^{1 *}$, Dwi Risma Deviyanti ${ }^{2}$ \\ 1,2 Program Studi Akuntansi, Universitas Mulawarman, Samarinda 75119, Indonesia \\ * Penulis korespondensi; Email: mhmmd_subhan@yahoo.com
}

\begin{abstract}
ABSTRAK
Pemahaman mengenai prinsip good corporate governance $(G C G)$ yang terdiri dari transparansi, akuntabilitas, responsibilitas, independensi, dan keadilan, memiliki peran penting dalam membangun kinerja sosial perusahaan untuk komunitas lokal, seperti harapan stakeholders. Penelitian ini bertujuan memperoleh pandangan umum mengenai tata kelola corporate social responsibility komunitas lokal di sekitar perusahaan tambang. Pendekatan penelitian ini adalah deskriptif kualitatif. Penelitian dilakukan di kota Samarinda dan Kutai Kartanegara, dengan asumsi kedua kota tersebut memiliki jumlah Mining Business License (IUP) terbanyak dibandingkan kota lain di provinsi Kalimantan Timur pada tahun 2015. Hasil penelitian ini menunjukkan manajemen CSR masih jauh dari harapan komunitas lokal, yang merupakan indikasi kinerja sosial perusahaan tambang yang buruk. Rendahnya corporate social performance perusahaan memunculkan potensi konflik di masa depan terkait dengan eksistensi perusahaan tambang. Hal ini akan mempengaruhi persepsi stakeholders lainnya seperti investor, pemerintah, dan komunitas yang lebih besar mengenai keberlanjutan operasional perusahaan di masa depan.
\end{abstract}

Kata kunci: Corporate social performance, good governance; masyrakat lokal, industri pertambangan.

\begin{abstract}
Understanding the principle of good corporate governance (GCG), which consists of transparency, accountability, responsibility, independence and fairness, plays an important role in generating social performance of companies (Corporate Social Performance) for local communities as expected by stakeholders. This research aims to obtain an overview of the governance of CSR in local communities around the coal mining company. These studies used descriptive qualitative method approach. Research carried out in the city of Samarinda and Kutai Kartanegara based on the assumption that the two cities have a Mining Business License (IUP) with the largest production status compared to other cities in the province of East Kalimantan in 2015. From this research known CSR management conditions are still far from the expectations of local communities is an indication of poor social performance of companies. Low Corporate Social Performance is a potential conflict in the future due to the low level of acceptance of the local community to the existence of the company. This will affect the perception of other stakeholders such as investors, government and the wider community about the continuity of the company's operations in the future.
\end{abstract}

Keywords: Corporate social performance; good governance; local community, mining industry.

\section{PENDAHULUAN}

Dengan semakin berkembangnya kesadaran banyak pihak akan pentingnya tata kelola perusahaan yang baik (good corporate governance) telah mendorong banyak perusahaan untuk menjaga hubungan dengan stakeholders. Perubahan pandangan dari model tradisional yang mengutamakan kepentingan pemegang saham menjadi mengutamakan kepentingan banyak pihak yang berkepentingan dengan perusahaan (stakehoders) untuk menjaga keseimbangan hubungan antara perusahaan dengan pihak lain yang berada di dalam maupun di luar perusahaan (Talaulicar 2010). 
Good Corporate Governance adalah sekumpulan mekanisme yang dapat melindungi pihakpihak minoritas di luar perusahaan, investor/ pemegang saham minoritas dari perampasan pihak manajemen dan pengendalian oleh pemegang saham dari pihak internal perusahaan dengan menekankan mekanisme hukum (Nur'ainy et. al. 2013). Sehingga mekanisme itu dapat mengatur manajer dalam pengambilan keputusan sesuai dengan keinginan shareholders dan stakeholders yang mengedepankan prinsip keadilan, transparansi dan akuntabilitas (Gillespie 2012).

Dengan mengadopsi corporate governance memiliki fungsi utama sebagai cara yang memungkinkan manajemen mengambil keputusan dalam area yang belum diatur (grey zones) dengan integritas (Wieland, 2005). Sehingga pengaturan yang efektif bagi stakeholders adalah ketika perusahaan mampu memberikan jaminan perlindungan terhadap hak-hak dan kepentingan mereka. Perlindungan tersebut dapat berupa hukum, aturan-aturan, kode etik perusahaan dan lain-lain yang diikuti oleh perusahaan. Hal tersebut akan meningkatkan kepercayaan stakeholders terhadap perusahaan (Rossouw 2005). Terdapat lima prinsip utama dalam penerapan GCG secara umum yang terdiri atas transparansi, akuntabilitas, responsibilitas, independensi dan keadilan (Nur'ainy et. al. 2013).

Corporate Social Responsibility (CSR) merupakan kegiatan yang bersifat sukarela dengan memberikan kontribusi barang-barang dan jasa serta keuangan kepada komunitas. Kegiatan tersebut tidak termasuk aktivitas yang terkait secara langsung kepada kegiatan produksi dan perdagangan perusahaan. Selain itu, kegiatan tersebut tidak termasuk aktivitas yang terkait dengan kepatuhan kepada pemerintah (Rodriguez dan Le Master 2007). Sehingga CSR merupakan tindakan nyata yang memberikan manfaat nilai tambah bagi perusahaan dan masyarakat. Selain itu CSR memiliki elemen penting yaitu perusahaan memberikan perhatian yang memadai atas kontribusinya kepada kesejahteraan masyarakat dalam jangka panjang (Rodriguez dan LeMaster 2007). Manfaat dari pelaporan CSR tersebut adalah meningkatkan akses modal yang lebih besar, biaya modal yang lebih rendah dan memberikan jaminan kepada investor baik dalam maupun luar negeri. Hal tersebut dapat tercapai karena dengan melaporkan kegiatan CSR maka pihak investor akan memiliki keyakinan kepada tata kelola perusahaan (corporate governance), sehingga dengan tata kelola perusahaan yang lebih baik berarti perusahaan mampu meminimalkan resiko dan menjamin kontinuitas usaha yang menguntungkan di masa mendatang (Rodriguez dan Le Master 2007).
Berdasarkan Corporate Citizenship Theory, menjelaskan bahwa adanya asumsi bahwa perusahaan dan masyarakat akan saling mempengaruhi dan perusahaan harus bertanggung jawab secara sosial terhadap lingkungan. Sehingga pada level dasar, perusahaan memiliki beberapa kewajiban kepada masyarakat di atas keuntungan. Kewajiban perusahaan dideskripsikan sebagai tanggung jawab sosial. Harapan sosial kepada perusahaan untuk memiliki kewajiban moral (Gibbs 2012). Kinerja Sosial Perusahaan (Corporate Social Performance) merupakan gabungan dari motivasi dan metode ke dalam satu kerangka tunggal dengan tambahan hasil (outcome). Kinerja sosial perusahaan melibatkan interaksi yang mendasari atau konfigurasi dari prinsip-prinsip tanggung jawab sosial (operating as motivator), proses tanggap sosial (social responsiveness process) dan hasil/kinerja. Konsep tersebut merupakan variasi dari setiap aspek CSP (motivasi, metode dan hasil). Sehingga perusahaan- perusahaan akan berbeda dalam konsep citizenship yang ditentukan oleh motivasi, proses dan hasil. Seberapa baik perusahaan melaksanakan beberapa tanggung jawab atau apakah mereka memiliki hubungan yang baik dengan stakeholders yang beragam (Gibbs 2012).

Bila dihubungkan dengan konsep kedermawanan (philanthropy theory), banyaknya sumbangan akan menguntungkan pemegang saham, tetapi tidak semua donasi sesuai dengan harapan pemegang saham. Maka kebutuhan perusahaan untuk menentukan program CSR yang tepat bagi masyarakat lokal sangatlah penting. Reputasi yang diperoleh perusahaan dari masyarakat akan dinilai sebagai kesesuaian antara harapan dan apa yang diperoleh masyarakat lokal didasarkan cara implementasi program CSR tersebut (Barktus et. al. 2002).

Penjelasan menurut stakeholder theory, bahwa organisasi akan tergantung dengan external stakeholders dalam menyediakan dukungan sumber daya dan kebalikannya, stakeholders akan menginginkan beberapa tindakan dari organisasi. Ketidakmampuan untuk melakukan tindakantindakan yang diinginkan esternal stakeholders akan memberikan dampak negatif bagi organisasi tersebut (Chan et. al. 2013). Oleh Karena itu sangatlah penting bagi perusahaan untuk menyediakan program-program CSR yang sesuai dengan kebutuhan masyarakat lokal. Karena kegagalan dalam memenuhinya akan menyebabkan biaya yang sangat tinggi dan kehilangan keuntungan dari peluang yang ada (Preston dan O'bannon 1997). Sehingga perusahaan harus memasukkan kegiatan CSR kedalam strategi perusahaan untuk memperoleh nilai kompetitif yang menjadi nilai 
strategis manajemen. Hal itu dapat dilakukan dengan melakukan pemetaan dampak sosial dari aktivitas rantai nilai dengan mengidentifikasi peluang-peluang untuk mengurangi dampak negatif dan memperoleh dampak positif (Gyves dan O'Higgins 2008).

Pemahaman mengenai perlunya kegiatan CSR (Corporate Social Responsibility) di Indonesia adalah hal yang baru, sehingga penerimaan akan pentingnya konsep tersebut masih dalam tahap perkembangan (Gillespie 2012). Di Indonesia, penerapan pelaporan CSR belum sepenuhnya dilakukan oleh banyak dunia usaha. Karena pola pemikiran yang lebih mengutamakan kepentingan pemilik perusahaan (shareholder) dibandingkan kepentingan stakeholders seperti masyarakat disekitar perusahaan, mitra bisnis dan karyawan. Penerapan pelaporan CSR merupakan gambaran perusahaan untuk memenuhi kewajibannya kepada stakeholders. Pelaksanaan kegiatan pertambangan di Kota Samarinda diatur melalui Peraturan Daerah Kota Samarinda No. 12 tahun 2013 dan Kabupaten Kutai Kartanegara diatur melalui Peraturan Daerah Kabupaten Kutai Kartanegara No. 2 tahun 2013. Tetapi dengan dikeluarkannya UU No. 23 Tahun 2014, maka pemerintah daerah di kabupaten dan Kota tidak lagi memiliki kewenangan untuk menerbitkan IUP (Izin Usaha Pertambangan). Kewenangan tersebut telah dilimpahkan kepada Pemerintah Provinsi Kalimantan Timur.

Kalimantan Timur dikenal sebagai daerah yang memiliki potensi sebagai penghasil batu bara. Hal ini dibuktikan dengan banyaknya penerbitan IUP oleh pemerintah daerah. Sampai dengan periode 2015, pemerintah daerah di Provinsi Kalimantan Timur sudah menerbitkan 1.192 IUP (Tabel 1). Daerah yang memiliki IUP dalam proses produksi dengan izin paling banyak adalah daerah Kabupaten Kutai Kartanegara dengan 218 IUP dan disusul oleh Kota Samarinda dengan 54 IUP. Perusahaan tambang batu bara yang beroperasi di Kabupaten Kutai Kartanegara adalah 217 perusahaan dengan luas wilayah tambang mencakup 345.716,33 hektar. Kota samarinda memiliki 55 perusahaan tambang batu bara dengan luas wilayah tambang mencakup 25.332,07 hektar.

Aktivitas tambang batu bara selalu diikuti dengan potensi kerusakan lingkungan yang sangat besar yang dapat berdampak kepada masyarakat sekitar perusahaan. Sehingga sangat penting bagi pihak perusahaan untuk memahami dan mengimplementasikan dengan benar konsep CSR. Hal tersebut diperlukan untuk menghindari adanya potensi konflik antara masyarakat dengan masyarakat lokal yang tinggal atau memiliki usaha di sekitar perusahaan.
Dari penjelasan diatas, maka peneliti akan melaksanakan penelitian yang bertema: "Pengaruh Implementasi GCG (Good Corporate Governance) Terhadap Kinerja Sosial Perusahaan (Corporate Social Performance)".

Penelitian ini bertujuan untuk memperoleh gambaran mengenai tata kelola CSR bagi masyarakat lokal yang tinggal dan bekerja di sekitar lingkungan daerah pertambangan batu bara. Pelaksanaan penelitian dilakukan di wilayah Kabupaten Kutai Kartanegara dan Kota Samarinda dengan asumsi ke dua daerah tersebut memiliki IUP dengan kegiatan produksi terbesar di Provinsi Kalimantan Timur.

\section{Pengaruh Transparansi Terhadap Kiner- ja Sosial Perusahaan (Corporate Social Performance)}

Transparansi merupakan suatu bentuk pengungkapan informasi dalam proses pembuatan suatu keputusan dan pengungkapan informasi serta informasi yang disampaikan merupakan informasi yang relevan tentang kegiatan CSR yang dilakukan oleh perusahaan (Nur'ainy et. al. 2013). Sehingga dalam pembuatan keputusan pada tahapan perencanaan hingga implementasi dapat diketahui oleh stakeholders, dalam hal ini adalah masyarakat lokal. Transparansi ini merupakan bentuk jaminan bahwa perusahaan telah melaksanakan kewajibannya kepada masyarakat lokal sesuai aturan pemerintah ataupun rencana yang telah disepakati dengan masyarakat.

Untuk menjaga objektivitas dalam menjalankan bisnis, perusahaan harus menyediakan informasi yang material dan relevan dengan cara yang mudah diakses dan dipahami oleh pemangku kepentingan (KNKG 2006). Untuk mendapatkan informasi maka ketersediaan sarana untuk mendapatkan informasi dari sumbernya sangatlah penting. Berdasarkan kondisi tersebut, maka perusahaan perlu menyediakan sarana yang mudah diakses dan dipahami masyarakat untuk mengetahui proses pelaksanaan egiatan CSR yang dilaksanakan dilingkungannya. Pengaruh Akuntabilitas Terhadap Kinerja Sosial Perusahaan (Corporate Social Performance) Akuntabilitas merupakan gambaran kejelasan fungsi, struktur dan sistem pengelolaan kegiatan CSR yang dilaksanakan oleh perusahaan, sehingga memberikan jaminan bahwa kegiatan tersebut dilaksanakan secara efektif (Nur'ainy et. al. 2013). Dengan kejelasan sistem pelaksanaan kegiatan CSR oleh perusahaan, maka perusahaan dapat mempertanggungjawabkan kegiatan CSR tersebut kepada masyarakat sekitar. Pemahaman tentang harapan masyarakat lokal akan membantu perusahaan yang beroperasi di daerah tersebut untuk 
Tabel 1. Izin Usaha Pertambangan di Provinsi Kalimantan Timur Tahun 2015

\begin{tabular}{llcrr}
\hline \multirow{2}{*}{ No. Kabupaten/Kota } & \multicolumn{2}{c}{ Tahapan Kegiatan } & \multirow{2}{*}{ Jumlah } \\
\cline { 3 - 4 } & & Eksplorasi & Produksi & 2 \\
\hline 1 & Kalimantan Timur & - & 2 & 127 \\
2 & Penajam Paser Utara & 93 & 34 & 268 \\
3 & Kutai Barat & 217 & 51 & 407 \\
4 & Kutai Kartanegara & 189 & 218 & 62 \\
5 & Samarinda & 8 & 54 & 154 \\
6 & Kutai Timur & 139 & 15 & 95 \\
7 & Berau & 80 & 15 & 77 \\
8 & Paser & 39 & 38 & 1.192 \\
\hline
\end{tabular}

Sumber: Dinas Pertambangan dan Energi Provinsi Kalimantan Timur

mengintegrasikan harapan tersebut ke dalam strategi CSR dan menyelaraskan dengan kepentingan perusahaan dan masyarakat di negara berkembang (Ogula 2012).

Keterlibatan masyarakat dalam proses perencanaan dan implementasi sangat diperlukan untuk memahami harapan masyarakat dalam kegian CSR. Sehingga perusahaan mampu meningkatkan keterlibatan masyarakat lokal dalam pelaksanaan kegiatannya. Penyelarasan harapan masyarakat dengan strategi CSR yang akan dimplementasikan akan meningkatkan efektifitas kegiatan tersebut.

\section{Pengaruh Tanggungjawab Terhadap Kinerja Sosial Perusahaan (Corporate Social Performance)}

Perusahaan harus mematuhi peraturan perundang-undangan serta melaksanakan tanggung jawab terhadap masyarakat dan lingkungan sehingga dapat terpelihara kesinambungan usaha dalam jangka panjang dan mendapat pengakuan sebagai good corporate citizen. Sehingga perusahaan mampu menjadi bagian dari komunitas lokal yang dapat mewujudkan komitmennya kepada masyarakat lokal (Nur'ainy et. al. 2013, KNKG 2006)

Keberadaan perusahaan dalam lingkungan masyarakat berarti perusahaan telah menjadi bagian dari masyarakat tersebut. Sehingga perusahaan memiliki tanggungjawab atas pengaruh dari kegiatan operasi yang ditimbulkannya dan berdampak bagi masyarakat disekitarnya (Gyves dan O'Higgins 2008).

\section{Pengaruh Independensi Terhadap Kiner- ja Sosial Perusahaan (Corporate Social Performance)}

Perusahaan harus bersikap independen dalam melaksanakan program CSR di lingkungan sekitarnya. Bersikap independen adalah perusahaan harus mampu untuk bebas dalam mengambil keputusan dengan pertimbangan dampak yang dimunculkannya kepada masyarakat sekitar. Sehingga perusahaan harus menghindari adanya conflict of interest dengan pihak lain yang dapat mempengaruhi perusahaan dalam mengambil kebijakan CSR (Nur'ainy et. al. 2013). Perusahaan harus dikelola secara independen sehingga masingmasing organ perusahaan tidak saling mendominasi dan tidak diintervensi oleh pihak lain (KNKG 2006). Sehingga perusahaan perlu untuk mengadakan departemen atau fungsi baik secara internal maupun eksternal yang secara khusus bertugas untuk mengelola kegiatan CSRnya.

\section{Pengaruh Keadilan Terhadap Kinerja Sosial Perusahaan (Corporate Social Per- formance)}

Dalam melaksanakan kegiatannya perusahaan senantiasa memperhatikan kepentingan pemegang saham dan pemangku kepentingan lainnya berdasarkan asas kewajaran dan kesetaraan (KNKG 2006, Nur'ainy et. al. 2013). Dari pernyataan tersebut tampak bahwa komunitas lokal merupakan salah satu stakholder yang harus mendapat perhatian yang sama dengan pihak lainnya mengingat masyarakat lokal merupakan pihak yang akan merasakan dampak yang ditimbulkan dari aktivitas perusahaan. Disisi yang lain, perusahaan memperoleh keuntungan dengan memunculkan kerusakan lingkungan di sekitar wilayah masyarakat di lokasi penambangan.

Kebutuhan perusahaan menggunakan aktivitas CSR untuk memberikan kontribusi kepada pengembangan komunitas yang berkelanjutan (sustainable community development) khususnya kepada masyarakat lokal untuk meningkatkan status sosial dan mendapatkan keungglan kompetitif yang akan mempengaruhi keberadaan perusahaan. Hal tersebut dapat terjadi, karena komunitas lokal telah mendapat informasi dengan baik mengenai dampak negatif yang muncul dari aktifitas perusahaan terhadap kehidupan generasi mereka di masa dating (Adewuyi dan Olowookere 
2010). Sehingga pengembangan komunitas yang berkelanjutan harus mampu memberikan pengaruh bagi kehidupan masyarakat sekitar dan generasi masa depan komunitas tersebut melalui program-program CSR yang dilakukan perusahaan tersebut.

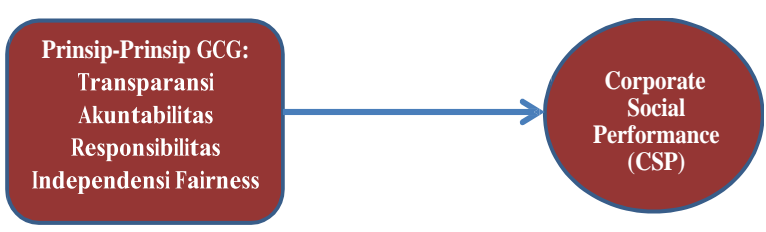

Gambar 1. Model Penelitian

\section{METODOLOGI PENELITIAN}

Kegiatan pengumpulan data dilakukan dengan menggunakan teknik survey pada masyarakat lokal yang bertempat tinggal di sekitar wilayah perusahaan tambang batu bara beroperasi. Lokasi surveya adalah daerah penambangan batu bara yang berada di Kota Samarinda dan Kabupaten Kutai Kartanegara. Untuk wilayah Kota Samarinda pengambilan data dilakukan di beberapa daerah yaitu Kelurahan Sambutan, Kelurahan Makroman, Kelurahan Pulau Atas, dan Kelurahan Tanah Merah. Untuk wilayah Kabupaten Kutai Kartanegara, pengambilan data dilakukan di Desa Jonggon, Desa Senoni, Desa Bangun Rejo dan Desa Karang Tunggal.

Dalam penelitan ini, populasi dalam pengambilan sampel ini adalah masyarakat lokal di sekitar wilayah perusahaan tambang batu bara beroperasi. Metode pengambilan sampel dengan purposive sampling yaitu berdasarkan suatu kriteria tertentu yaitu masyarakat lokal yang bertempat tinggal sekitar wilayah perusahaan tambang batu bara. Pengumpulan data dilakukan melalui observasi, wawancara dan dokumentasi (Rosada dan Nurliani, 2015).

Penelitian ini berusaha mengungkapan kinerja sosial perusahaan dengan memperhatikan fenomena sosial yang terjadi melalui persepsi rensponden.

Data dianalisis dengan menggunakan pendekatan metode kualitatif deskriptif Sehingga akan diperoleh gambaran tata kelola CSR dengan menggunakan indikator-indikator pengukuran GCG (Good Corporate Governance) yang merupakan ukuran Kinerja Sosial Perusahaan (Corporate Social Performance) yang dihasilkan pada tahun pertama dilihat dari sudut pandang masyarakat lokal yang tinggal di sekitar daerah penambangan.

Dalam penelitian ini, prinsip-prinsip GCG diukur dengan menggunakan beberapa indikator yang merupakan ukuran Kinerja Sosial Perusahaan (Corporate Social Performance) yaitu:
1. Transparansi (Transparency). Beberapa indikator yang digunakan adalah:

a. Kemudahan memperoleh informasi.

b. Ketersediaan saluran komunikasi.

c. Kemudahan menggunakan saluran komunikasi.

d. Kelengkapan informasi.

2. Akuntabilitas (Accountability).

Beberapa indikator yang digunakan adalah:

a. Keterlibatan masyarakat dalam pemetaan permasalahan sosial, lingkungan dan ekonomi.

b. Keterlibatan masyarakat dalam pelaksanaan kegiatan CSR.

c. Pemahaman masyarakat dengan kebijakankebijakan yang digunakan oleh perusahaan.

d. Kebijakan-kebijakan yang digunakan merupakan hasil kesepakatan antara masyarakat lokal dan perusahaan.

3. Tanggung Jawab (Responsibility).

Beberapa indikator yang digunakan adalah:

a. Perusahaan dapat mengatasi dampak negatif yang muncul dari aktivitasnya terhadap lingkungan masyarakat.

b. Perusahaan dapat memenuhi komitmennya kepada masyarakat.

c. Perusahaan dapat menindaklanjuti masukan-masukan dari masyarakat untuk memperbaiki pelaksanaan program CSR yang dilakukannya.

d. Perusahaan dapat menindaklanjuti masukan-masukan dari masyarakat untuk memperbaiki aktivitasnya yang mengganggu lingkungan.

4. Kebebasan (Independency). Beberapa indikator yang digunakan adalah:

a. Pengelola kegiatan CSR adalah lembaga yang khusus.

b. Keterlibatan masyarakat lokal pengawasan kegiatan CSR.

Keterllibatan pihak-pihak yang ahli dan Lembaga Swadaya Masyarakat (LSM) dalam menangani masalah masalah khusus seperti masalah lingkungan.

5. Keadilan (Fairness). Beberapa indikator yang digunakan adalah:

a. Perusahaan dapat meningkatkan kondisi perekonomian.

b. Kompensasi yang adil terhadap kerugian yang diderita masyarakat lokal atas kerusakan lingkungan yang ditimbulkannya.

c. Pembangunan fasilitas umum bagi masyarakat lokal.

\section{HASIL DAN PEMBAHASAN}

Responden penelitian ini berjumlah 100 orang. Survey dilakukan dengan melakukan interview 
secara langsung kepada responden. Responden yang diinterview adalah 50 orang di Kota Samarinda dan 50 orang disebarkan di Kabupaten Kutai Kartanegara.

Dari hasil interview pada tabel 2, diketahui bahwa dari indikator pengukuran 1 hingga 18 memberikan pola yang serupa. Sebagian besar responden yaitu diatas $60 \%$ menyatakan tidak setuju terhadap setiap pertanyaan yang diberikan.

\section{$\underline{\text { Transparansi }}$}

Dari hasil interview dengan responden penelitian terlihat kurangnya implementasi prinsip transparansi dalam kegiatan CSR yang dilakukan oleh perusahaan menyebabkan rendahnya kinerja sosial perusahaan. Mengenai kemudahan dalam mendapatkan informasi CSR oleh masyarakat, mayoritas responden sebesar $87 \%$ menyatakan tidak mudah untuk memperoleh informasi CSR dari perusahaan. Hasil yang sama tampak searah dengan penyediaan sarana komunikasi yang khusus bagi masyarakat untuk mengetahui kegiatan CSR, mayoritas responden sebesar $90 \%$ menyatakan bahwa perusahaan tidak menyediakan sarana komunikasi yang khusus bagi mereka untuk mengetahui kegiatan CSR perusahaan.

Sementara saluran komunikasi yang sering digunakan oleh masyarakat baik langsung datang ke perusahaan (melalui humas) atau pun contact person di dalam perusahaan, masyarakat sangat sulit untuk mendapatkan informasi. Hal ini dapat dilihat dari jawaban responden atas pernyataan bahwa masyarakat dapat menggunakan saluran komunikasi yang disediakan oleh perusahaan dengan mudah untuk mendapatkan informasi mengenai CSR perusahaan, sebagian besar responden sebesar 91\% menjawab tidak mudah untuk menggunakan saluran komunikasi yang disediakan oleh perusahaan. Berdasarkan kondisi dilapangan perusahaan akan membuka komunikasi dengan masyarakat ketika masyarakat melakukan tindakan-tindakan yang akan merugikan perusahaan, seperti penutupan jalan ke lokasi tambang yang melalui wilayah masyarakat setempat dan demonstrasi.

Hal serupa juga tampak sama atas respon dari responden mengenai perusahaan selalu memberikan informasi yang memadai mengenai ke- bijakan-kebijakan yang digunakan dalam pelaksanaan kegiatan. Mayoritas responden sebesar $89 \%$ menyatakan bahwa perusahaan tidak memberikan informasi yang memadai mengenai kebijakan-kebijakan CSR yang dilaksanakannya. Selama ini pelaksanaan kegiatan CSR yang dilakukan perusahaan jarang mendengarkan pendapat dari masyarakat. Hampir seluruh kebijakan-kebijakan CSR perusahaan baik dalam hal kelayakan nilai ganti rugi dan kegiatan sosial lainnya tidak pernah dikomunikasikan dengan masyarakat. Sehingga sering muncul kecemburuan antara sebagian kecil masyarakat yang mendapatkan dana ganti rugi dengan sebagian besar masyarakat yang tidak mendapatkan dan besaran ganti rugi yang diberikan antara masyarakat setempat.

\section{$\underline{\text { Akuntabilitas }}$}

Sebelum pelaksanaan kegiatan CSR, adalah penting bagi suatu perusahaan melakukan pemetaan atas kondisi sosial, ekonomi dan lingkungan masyarakat di sekitarnya. Sehingga keterlibatan masyarakat dalam proses perencanaan dan pelaksanaan program CSR adalah hal yang utama. Dari informasi tersebut, maka perusahaan dapat menentukan program CSR yang tepat bagi masyarakat. Selain itu, keterlibatan masyarakat dalam perencanaan dan pelaksanaan kegiatan CSR akan memperjelas sistem pengelolaan kegiatan CSR yang dilakukan perusahaan terutama dalam penyusunan kebijakan- kebijakan CSR. Sehingga dengan keterilbatan masyarakat sekitar diharapkan perusahaan mampu memenuhi harapan masyarakat dan mempertanggungjawabkan hasil kegiatan CSR kepada masyarakat sekitarnya.

Sebagian besar responden $88 \%$ menyatakan bahwa mereka tidak setuju dengan pernyataan bahwa masyarakat dilibatkan dalam proses pemetaan permasalahan sosial, lingkungan dan ekonomi di lingkungannya. Hal serupa juga tampak dari ketidak setujuan mayoritas responden sebesar $88 \%$ atas pernyataan bahwa masyarakat lokal dilibatkan dalam pelaksanaan kegiatan CSR yang dilakukan perusahaan di lingkungan mereka.

Akibat tidak terlibatnya mayoritas masyarakat dalam pelaksanaan kegiatan CSR yang

Tabel 2. Hasil Interview Responden

\begin{tabular}{|c|c|c|c|c|c|c|c|c|c|c|c|c|c|c|c|c|c|c|}
\hline \multirow{2}{*}{ Ket. } & \multicolumn{18}{|c|}{ INDIKATOR PENGUKURAN (\%) } \\
\hline & 1 & 2 & 3 & 4 & 5 & 6 & 7 & 8 & 9 & 10 & 11 & 12 & 13 & 14 & 15 & 16 & 17 & 18 \\
\hline Setuju & 11 & 9 & 4 & 4 & 9 & 7 & 8 & 6 & 16 & 16 & 19 & 18 & 14 & 11 & 19 & 29 & 13 & 15 \\
\hline Ragu-ragu & 2 & 1 & 5 & 7 & 3 & 5 & 3 & 10 & 10 & 5 & 8 & 7 & 9 & 6 & 7 & 11 & 3 & 2 \\
\hline Tidak Setuju & 87 & 90 & 91 & 89 & 88 & 88 & 89 & 84 & 74 & 79 & 73 & 75 & 77 & 83 & 74 & 60 & 85 & 84 \\
\hline
\end{tabular}


dilakukan oleh perusahaan menyebabkan ketidakpahaman masyarakat atas program CSR yang dilaksanakan oleh perusahaan. Hal ini tampak dari ketidaksetujuan sebagian besar responden yaitu $89 \%$ atas pernyataan bahwa masyarakat lokal paham dengan kebijakankebijakan yang diambil perusahaan dalam pelaksanaan kegiatan CSR di lingkungan mereka. Hasil yang sama juga terlihat dari pernyataan bahwa kebijakan-kebijakan dalam pelaksanaan program CSR yang dijalankan merupakan hasil kesepakatan antara masyarakat local dan perusahaan. Dimana sebagian besar responden yaitu $84 \%$ menolak pernyataan tersebut.

\section{Tanggungjawab}

Kondisi diatas adalah masalah-masalah yang ditemukan di lokasi penelitian. Rendahnya tingkat tanggung jawab perusahaan tampak dari hasil yang diperoleh dari hasil penelitian ini. Sebagian besar responden yaitu $74 \%$ menyatakan bahwa perusahaan tidak dapat mengatasi dampak negatif yang muncul dari aktivitasnya terhadap lingkungan masyarakat sekitarnya. Hal senada juga tampak dari persetujuan mayoritas responden sebesar $79 \%$ yang menyatakan bahwa perusahaan tidak dapat memenuhi komitmennya kepada masyarakat sekitar melalui program CSR yang dilakukannya.

Selain permasalahan tersebut diatas, sebagian besar responden sebesar $73 \%$ menganggap perusahaan tidak pernah menindaklanjuti masukan-masukan dari masyarakat lokal untuk memperbaiki pelaksanaan program CSR yang dilakukannya. Kondisi yang sama juga tampak dari kesamaan pendapat responden sebesar $74 \%$ atas pendapat bahwa perusahaan tidak pernah menindaklanjuti masukan-masukan dari masyarakat lokal untuk memperbaiki aktivitasnya yang mengganggu lingkungan masyarakat sekitar.

Kondisi yang tampak dari hasil penelitian ini menggambarkan rendahnya keinginan perusahaan dalam memenuhi kewajibannya terutama dampak yang ditimbulkan dari aktivitas yang merusak lingkungan. Sehingga banyak masyarakat yang cenderung untuk melakukan tindakantindakan yang dapat merugikan perusahaan agar perusahaan memperhatikan keluhan-keluhan masyarakat. Hal tersebut dapat mengindikasikan ancaman bagi kelangsungan usaha dari perusahaan. Independensi Kondisi independensi tercermin dari bagaimana tata kelola program CSR dapat dirasakan oleh masyarakat sekitar dari cara-cara program CSR itu dilaksanakan. Dalam penelitian ini, tampak mayoritas responden sebesar $77 \%$ merasa bahwa pihak yang mengelola kegiatan CSR bukanlah departemen yang secara khusus dibentuk di dalam perusahaan atau lembaga di luar perusahaan yang menangani program CSR. Selain itu, sebagian besar responden yaitu 83\% menyatakan bahwa masyarakat lokal tidak dilibatkan dalam pengawasan kegiatan CSR yang dilaksanakan oleh perusahaan.

Perusahaan melibatkan pihak-pihak yang ahli dalam bidang tertentu untuk menangani masalah-masalah yang muncul dari kegiatannya seperti masalah lingkungan. Tetapi dari kondisi di lapangan, ketidakmampuan perusahaan dalam menangani masalah lingkungan yang muncul menggambarkan bahwa tata kelola dalam mengendalikan kerusakan lingkungan adalah tidak sesuai dengan yang seharusnya. Hal ini sejalan dengan pendapat sebagian besar responden $74 \%$ yang menyatakan bahwa perusahaan tidak melibatkan pihak-pihak yang ahli dan LSM dalam menangani masalah-masalah yang khusus seperti lingkungan.

\section{$\underline{\text { Keadilan }}$}

Dari kondisi di lokasi penelitian tampak bahwa program CSR yang dilakukan perusahaan hanya bersifat jangka pendek atau hanya untuk mengurangi gejolak di masyarakat akibat dampak negatif yang dimunculkan dari aktivitasnya. Hal ini tampak dari hasil penelitian yang dilakukan. Penciptaan lapangan kerja bagi masyarakat hanya sebatas penerimaan karyawan harian dan dalam jumlah yang sangat terbatas dan tidak ada usaha perusahaan untuk memberdayakan masyarakat sekitar seperti melalui program pelatihan dan pemberian modal kerja. Sebagian besar responden yaitu $60 \%$ menyatakan bahwa perusahaan tidak menciptakan lapangan kerja yang memadai bagi masyarakat.

Hal serupa juga terlihat dari besarnya kompensasi yang diberikan perusahaan untuk mengganti kerugian yang diderita oleh masyarakat sekitar yang muncul dari aktivitasnya. Hal ini dikarenakan penentuan besarnya kerugian dilakukan secara sepihak oleh perusahaan. Sehingga masyarakat merasakan kompensasi yang diberikan tidak sesuai dengan kerugian yang dideritanya. Dari hasil kuesioner tampak bahwa sekitar $84 \%$ responden merasa ganti rugi yang diberikan oleh perusahaan tidak sesuai dengan kerugian yang mereka derita.

Hasil yang sama juga tampak pada usaha perusahaan untuk membangun fasilitas umum bagi masyarakat sekitar. Sebesar $83 \%$ menyatakan bahwa perusahaan tidak mengutamakan pembangunan fasilitas umum bagi masyarakat. Pembangunan fasilitas umum oleh perusahaan 
hanya dilakukan sebatas perbaikan karena kerusakan fasilitas umum yang disebabkan oleh aktivitas perusahaan itu sendiri seperti perbaikan jalan. Usaha perbaikan itu pun tersebut terkesan terpaksa setelah mendapat peringatan dan aktivitas penutupan lokasi jalan ke perusahaan oleh masyarakat.

Dari penjelasan diatas, terlihat penerapan prinsip keadilan yang dilakukan perusahaan tambang di Kalimantan Timur khususnya di Kota Samarinda dan Kabupaten Kutai Kartanegara masih jauh dari yang seharusnya. Program CSR yang dilakukan perusahaan hanya sebatas merupakan bentuk untuk mengurangi gejolak di masyarakat sekitar dan bersifat ganti rugi. Program CSR yang dilakukan perusahaan belum menyentuh aspek pemberdayaan masyarakat (community development).

\section{KESIMPULAN DAN SARAN}

Dari hasil penelitian ini dapat disimpulkan bahwa:

1. Kondisi rendahnya implementasi faktor-faktor transparansi, akuntabilitas, responsibilitas, independensi dan keadilan mengakibatkan rendahnya kinerja sosial perusahaan tambang batu bara di Kalimantan Timur khususnya di Kota Samarinda dan Kabupaten Kutai Kartanegara.

2. Rendahnya implementasi transparansi mempengaruhi kinerja sosial perusahaan dikarenakan kesulitan memperoleh informasi, ketiadaan sarana komunikasi yang khusus, kesulitan menggunakan akses informasi yang disediakan dan ketidaklengkapan informasi yang diberikan.

3. Akuntabilitas yang rendah memberikan pengaruh terhadap kinerja sosial perusahaan melalui ketiadaan masyarakat dalam proses pemetaan permasalahan dan pelaksanaan kegiatan CSR, ketidakpahaman masyarakat dengan kebijkan-kebijakan yang digunakan perusahaan, dan kebijakan- kebijakan tersebut bukan hasil dari kesepakatan antara masyarakat dengan perushaan.

4. Implementasi responsibilitas yang rendah menyebabkan rendahnya kinerja sosial perusahaan karena ketidakmampuan perusahaan dalam mengatasi dampak negatif dari aktivitasnya, ketidakmampuan perusahaan memenuhi komitmennya dengan masyarakat, dan tidak ditindaklanjutinya masukan-masukan dari masyarakat untuk memperbaiki aktivitas operasi dan CSRnya.

5. Faktor independensi yang rendah mempengaruhi rendahnya kinerja sosial perusahaan dikarenakan pihak pengelola CSR bukanlah lem- baga yang dibentuk secara khusus, masyarakat tidak dilibatkan dalam pengawasan kegiatan, dan perusahaan tidak melibatkan pihakpihak yang ahli dalam menangani masalahmasalah lingkungan yang khusus.

6. Implementasi prinsip keadilan yang rendah mengakibatkan rendahnya kinerja sosial perusahaan dikarenakan perusahaan tidak menciptakan lapangan kerja yang memadai bagi masyarakat, ganti rugi yang diberikan oleh perusahaan tidak sesuai dengan kerugian yang mereka derita dan perusahaan tidak mengutamakan pembangunan fasilitas umum bagi masyarakat.

Daritemuan-temuan dilapangan terkait faktor-faktor implementasi GCG yang mempengaruhi kinerja sosial perusahaan, maka berikut ini saransaran yang diberikan untuk meningkatkan kinerja sosial perusahaan:

1. Untuk meningkatkan kinerja sosial perusahaan maka perlu adanya perbaikan implementasi transparansi antara pihak perusahaan dengan masyarakat lokal yang mencakup:

a. Menyediakan sarana komunikasi yang memadai dan mudah untuk digunakan oleh seluruh masyarakat sekitar perusahaan dan tidak hanya bagi kelompok kecil masyarakat seperti melalui pertemuan warga yang dilakukan secara terus menerus untuk melakukan evaluasi terhadap program CSR perusahaan.

b. Memberikan informasi yang memadai kepada masyarakat sehingga informasi mengenai pelaksanaan kegiatan CSR dapat diketahui seluruh masyarakat dan tidak hanya bagi kelompok kecil masyarakat. Seperti kebijakan-kebijakan yang dibuat untuk kegiatan CSR perusahaan dikomunikasikan dengan seluruh warga.

2. Peningkatan kinerja sosial perusahaan dapat dilakukan dengan perbaikan implementasi akuntabilitas melalui:

a. Melibatkan masyarakat dalam proses pemetaan permasalahan sosial, lingkungan dan ekonomi di lingkungannya. Sehingga program CSR yang diimplementasikan dapat sesuai dengan harapan masyarakat sekitar perusahaan.

b. Masyarakat lokal dilibatkan dalam pelaksanaan kegiatan CSR yang dilakukan perusahaan di lingkungan mereka sehingga akan meningkatkan tingkat kepercayaan masyarakat kepada perusahaan.

c. Kebijakan-kebijakan yang dibuat dalam melaksanakan kegiatan CSR seharusnya merupakan kesepakatan bersama antara 
masyarakat dengan perusahaan. Sehingga dapat diterima dan sesuai dengan harapan masyarakat terkait kebijakankebijakan programa CSR yang dilaksanakan oleh perusahaan.

3. Peningkatan kinerja sosial perusahaan dengan peningkatan implementasi responsibilitas melalui:

a. Perusahaan harus mengatasi dampak negatif yang muncul dari aktivitasnya terhadap lingkungan masyarakat sekitarnya. Sehingga perusahaan harus menerima masukanmasukan dari masyarakat sekitar perusahaan agar dapat mengidentifikasi masalah yang harus diselesaikan. Sehingga aktivitas perusahaan tidak mengganggu lingkungan masyarakat sekitar.

b. Perusahaan harus memenuhi komitmennya kepada masyarakat sekitar melalui program CSR yang dilakukannya. Maka peran aktif masyarakat dalam memberi masukan harus ditindaklanjuti. Sehingga membantu perusahaan untuk memperbaiki program CSR yang dilakukannya agar sesuai harapan masyarakat.

4. Peningkatan kinerja sosial perusahaan dengan peningkatan implementasi independensi melalui:

a. Perusahaan harus membuat fungsi yang khusus menangani program CSR di dalam perusahaan ataupun diluar perusahaan sehingga kebijakan-kebijakan CSR yang dibuat tidak dipengaruhi oleh departemen yang lain atau oleh pihak lain (conflict of interest) dan sesuai dengan harapan masyarakat sekitar.

b. Perusahaan melibatkan masyarakat lokal dalam kegiatan pengawasan pelaksanaan kegiatan CSR yang dilakukan. Sehingga perusahaan dapat memperbaiki implementasi program CSR yang dilaksanakan ketika ditemui adanya penyimpangan.

c. Perusahaan melibatkan pihak-pihak yang ahli atau LSM dalam menangani masalahmasalah khusus seperti kerusakan lingkungan yang disebabkan kegiatan operasinya. Sehingga perusahaan dapat menyelesaikan masalah lingkungan yang mengganggu masyarakat sekitar areal penambangan.

5. Peningkatan kinerja sosial perusahaan dengan peningkatan implementasi keadilan melalui:

a. Perusahaan harus mampu menciptakan lapangan kerja yang memadai bagi masyarakat sekitar baik melalui penerimaan tenaga kerja dengan status karyawan tetap atau melalui pelatihan-pelatihan dan pem- berian modal usaha sehingga mendorong perbaikan kondisi sosial masyarakat.

b. Ganti rugi kepada masyarakat harus sesuai dengan kerugian yang diderita masyarakat. Sehingga perlu bagi perusahaan mensosialisasikan kebijakankebijakan yang dibuat sebagai dasar pemberian ganti rugi. Serta mengajak masyarakat untuk berdiskusi dalam menyusun kebijakan-kebijakan ganti rugi tersebut.

c. Perusahaan harus mengutamakan peningkatan kondisi lingkungan masyarakat sekitar dengan mengutamakan pembangunan fasilitas-fasilitas umum bagi masyarakat, tidak hanya perbaikan atas fasilitas umum yang rusak karena aktivitas perusahaan itu sendiri

\section{DAFTAR PUSTAKA}

Adewuyi, Adeolu O. and Olowookere, Afolabi E. (2010). CSR and Sustainable Community Development in Nigeria: WAPCO, a case from the cement industry. Social Responsibility Journal. 6(4), 522-535.

Barktus, Barbara R; Morris, Sara A. and Seifert, Bruce. (September 2002). Governance and Corporate Philathropy. Restraining Robin Hood? Business and Society, 41(3), ProQuest Sociology.

Chan, Mui Ching Carina: Watson, John and Woodliff David (2013). Corporate Governance Quality and CSR Disclosure. Journal Business of Ethics, 59-73.

Gibbs, Carole (2012). Corporate Citizenship and Corporate Environmental Performance. Crime Law Social Change, 345-372.

Gillespie, Piers. (June 2012). The Challenges of Corporate Governance in Indonesian Oil Palm: Opportunities to Move Beyond Legalism? Asian Studies Review, 36, 247269.

Gyves, Sharon and O'Higgins Eleanor. (2008). Corporate Social Responsibility: An Avenue for Sustainable Benefit for Society and the Firm? Society and Business Review, 3(3), 207 223 Emerald Group Publishing Limited.

KNKG. (2006). Pedoman Umum Good Corporate Governance Indonesia.

Moleong, Lexy J. (2006). Metodologi Riset Kualitatif. Pustaka Pelajar. Yogyakarta.

Nur'ainy, Renny; Nurcahyo, Bagus; Kurniasih A, Sri; dan Sugiharti B. (2013). Implementation of Good Corporate and Its Impact on Corporate Performance: The Mediation Role of Firm Size (Empirical Study From Indonesia). Global Business Management Research: an International Journal, $5(2 \& 3)$. 
Ogula, David. (2012). Corporation Social Responsibility: Case Study of Community Expectations and The Administrative Systems, Niger Delta. The Qualitative Report 2012, 17.

Preston, Lee and O’Bannon, Douglas P. (Dec. 1997). The Corporate Social- Financial Performance Relationship. A Typology and Analysis. Business and Society. 36(4). ProQuest Sociology.

Rodriguez, Linda $\mathrm{C}$ and LeMaster, Jane. (September 2007). Voluntary Corporate Social Responsibility Disclosure. SEC "CSR Seal of Approval. Business \& Society. 46(3).

Rosada, Ida; Nurliani (2016). A Review on Multi Roles of Women and Their Influence on the Change of Functional Structure in the
Farmer's Household. International Conference on Food, Agriculture and Natural Resources. Agriculture and Agricultural Science Procedia, 9, 47-53.

Rossouw, G. J. (March 2005). Business Ethics and Corporate Governance, A Global Survey. Business and Society, 44(1), ProQuest Sociology.

Talaulicar, Till. (2010). The Concept of the Balanced Company and Its implications for Corporate Governance. Society and Business Review. 5(3), www.emeraldinsig-ht.com/746-5680.htm.

Wieland, Josef. (March 2005). Corporate Governance, Values Management, and Standars: A European Perspective. 44(1), ProQuest Sociology. 